\title{
INTEGRATED MANAGEMENT OF HOUSEHOLD SOLID WASTE
}

\author{
Ma. Neftali Rojas-Valencia. \\ National Autonomous University of Mexico, Mexico.
}

\begin{abstract}
In Mexico City an average urban family (made up of five members) produces a cubic meter of domestic solid waste every month. This is equivalent to $1.5 \mathrm{~kg}$ per person per day. Domestic solid wastes are responsible for 5,640 tons/day of the 11,990 tons/day generated in the Federal District (DGSU, GDF, 2006). According to INE, $77 \%$ of solid waste in the municipal area comes from homes.
\end{abstract}

The domestic solid waste problem is heightened by the unfettered production generated by the consumerist system. The overvaluation that people give to the products that they consume stems from both lack of knowledge and insensitivity - many people only care about acquiring things, without taking into account the impact that this has on the environment. To make matters worse, Mexico City is lacking in regulations that oblige companies to only produce returnable - or at least recyclable - products, which makes the accumulation and separation of materials even more difficult.

To help diminish this solid waste production, households must take the initiative to incorporate into their development plans measures for the adequate management of solid waste. As such, the object of this work was to create in households a responsible attitude in the care and environmental conservation to foment the separation and assist in the recycling of solid waste. To achieve this objective, a guide was made in which different waste management and separation alternatives were established. The guide also discusses diminished costs associated with these practices, as well as other benefits. Various options for composting in housing developments are given, and methods for cultivating plants using organic and inorganic residues are described. Finally, the guide gives recommendations for reducing and regulating construction wastes. The households that incorporate the guide's suggestions help to create a clean, sustainable planet.

\section{KEYWORDS}

Integrate Management; Household; Solid Waste.

\section{INTRODUCTION}

Over the course of recent years, the problem of solid waste management has worsened, not just by the amount expected by increasing population, but also due to qualitative changes in residual waste composition. This has both political and economic implications [1].

The INEGI [2] has measured total daily countrywide waste production in Mexico to be 85,633 tons. Of this quantity, Mexico City contributed 12,219 tons/ day in 2005 and 11,990 tons/day in 2006. This waste was produced by the $8,605,239$ members of the district's fixed 
population plus the "floating" population that enters the metropolitan zone daily. Of this total amount $50 \%$ is composted of organic wastes and $34 \%$ are recyclable [3].

Currently, the average family in Mexico City (composed of 5 members) produces a cubic meter of trash every month $(1.5 \mathrm{~kg} /$ person/day). Total domestic waste includes wastes produces in single- and multi-family dwellings, which generate 5,640 tons/day, or $20 \%$ of the total generated in the Federal District [3]. According to INE, $77 \%$ of municipal solid waste originating from households was measured.

\section{TECHNICAL FOUNDATION}

It is vitally important that the amount waste generated does not continue to increase, for various reasons: 1) Environmental pollution is severe due to the improper disposal of solid wastes, 2) Natural resources are being choked off with the production of goods that are disposed of without any consideration whatsoever [4], and 3) there are insufficient controlled sites for disposing of all the wastes that are generated. Mexico City only contains one adequate location for waste disposal, The Sanitary Landfill of Bordo Poniente State IV, where $70 \%$ of the city's waste is brought. The landfill is insufficient for disposing of all of the wastes produced by the population.

With the goal of reducing this problem, on October 8, 2003, the General Law for the Prevention and Management of Wastes [5] was passed with the objective of promoting sustainable development through the prevention, valuation, and the integrated management of wastes. On the $20^{\text {th }}$ of March 2003, the Law of Solid Waste of the Federal District was established [6]; the law states that all inhabitants of the Capital District must separate organic from inorganic wastes in their homes [7].

A grand campaign was launched to foment household waste separation, although initial enthusiasm was truncated by the lack of infrastructure and education, which led to widespread desertion of people's good intentions for waste separation when they saw that all waste was being hauled away in waste trucks without any separation.

These types of stories are those that mar educational campaigns, as people come to feel that their efforts are in vain, and that they are better off abandoning them. Any future programs that are launched must take into account the errors that have been committed so that they are not repeated. The following objective seeks to adequately increase public consciousness.

\section{GENERAL OBJECTIVE}

Foment a change in household habits in order to promote the practice of waste separation into three main categories: organic, reusable, and recyclable, with the aim of recuperating products within wastes that have commercial value.

\section{Specific Objectives:}

- Establish permanent educational programs to establish knowledge/sensitivity through a campaign of information, assistance, and supervision.

- Educate the community about the responsibility that it has as generator of its own trash and about the importance of contributing to the separation of recyclable or reusable wastes. 
- Synthesize measures that can be adopted to separate and adequately manage solid wastes.

- Educate and increase consciousness about waste separation in susceptible subcategories such as metals, glass, paper, plastic, and organic material.

- Promote the production of compost at a household level as an alternative for the management of organic wastes.

- Encourage the practice of home vegetable gardening using organic and inorganic wastes.

\section{METHODOLOGY}

An easy method of remembering what must be done is to follow the rule of the 6 R's.

\section{Respect}

If we consider and remember that all we consume comes from nature, we should realize that it is better to consume only what is necessary for our wellbeing. Avoid buying products that come from animals in extinction danger (See figure 1).
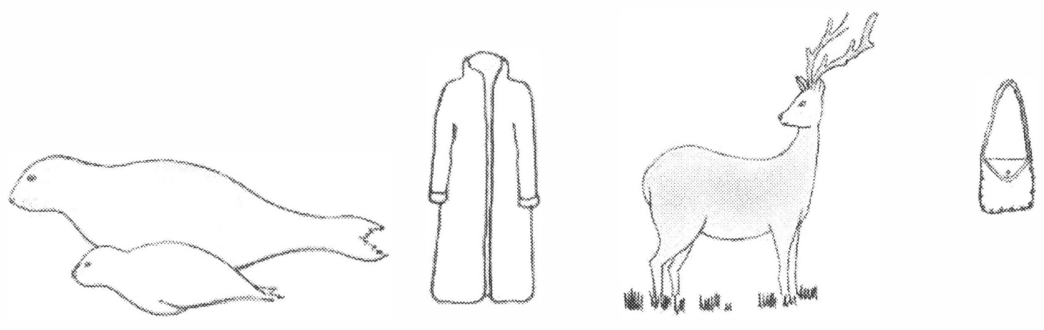

Figure 1. Products that come from animals in extinction danger

\section{Reject}

It is important to avoid buying products that, either because of their packaging or their composition, harm the environment, as they come in metallic bags, Styrofoam boxes, or nonrecyclable plastic containers. We also pay for any decoration on the packaging, and as these become waste, we essentially throw away our money as well.

\section{Reduce}

To reduce is to prevent, limit, and avoid generating unnecessary wastes. When choosing between two similar products, choose the one with less packaging (See figure 2). 


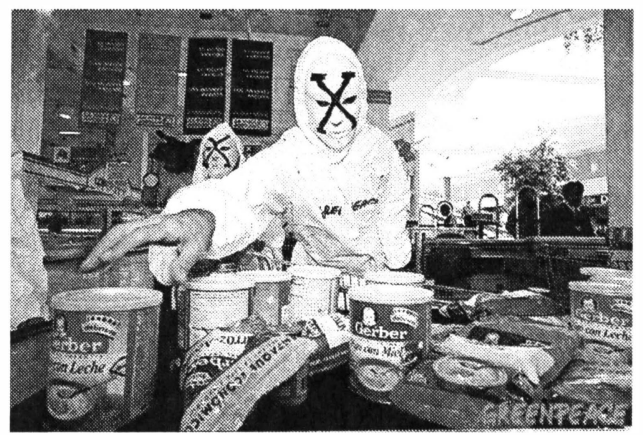

Figure 2. Choose the one with less packaging. Source: Greenpeace.

\section{Reuse}

To reuse is to continue using an article or element thereof after it has been used for the first time. There is not necessarily a transformation between the original use and subsequent uses (See figure 3).

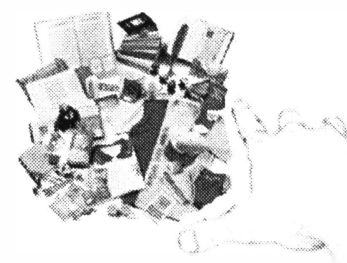

Figure3. To reuse before throwing

\section{Recycle}

Recycling is a process which takes advantage of and transforms residual solid wastes for use as raw materials in the fabrication of new products. Wastes such as paper, plastic, glass, cardboard, and metal can be recycled, among others (See figure 4). 


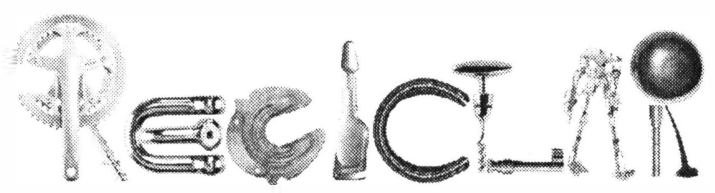

Figure 4. Recycling

\section{Responsibility}

Responsibility is the commitment we must make to accomplish the other 5Rs, informing ourselves well about the appropriate management of solid wastes and ultimately sharing our knowledge with other people.

\section{PRODUCTS AND/OR RESULTS}

The products of this work are:

- Selection of the basic rules for the management of household solid wastes.

- Identification of different alternatives for recycling household solid wastes.

- Description of different options for the creation of compost.

Development of methods for cultivating vegetable crops in urban dwellings, utilizing organic and inorganic wastes

Synthesis of management alternatives for construction wastes and ways to minimize these wastes

As a final result we may achieve a clean, sustainable planet for future generations (See figure 5).

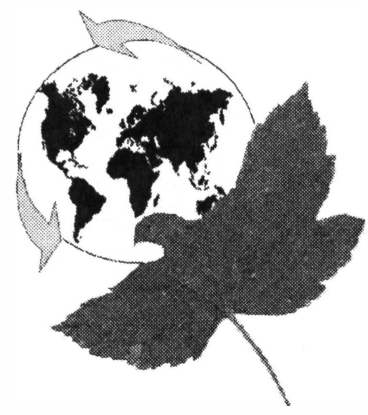

Figure 5. Sustainable planet 


\section{ENVIRONMENTAL IMPACT}

In Mexico, environmental education is inadequate. It does not meet the country's requirements, does not follow scientific and technical advances, and is not updated for the grave environmental problems that surfaced at the end of the $20^{\text {th }}$ century.

To have a clean, safe environment programs must be established to increase consciousness about the management of solid wastes, thus creating a new environmental culture. Government, business, and citizenry must work in conjunction in such a manner that encourages waste separation and avoids polluting water and soil.

If public consciousness can be raised through the establishment of such a program, pollution due to solid wastes would be reduced by at least $80 \%$. Through recycling, we can decrease the impact that human activity has on the environment.

Recuperating materials that can be recycled helps to conserve natural resources, and reducing waste helps to decrease subsoil contamination (See figure 6).

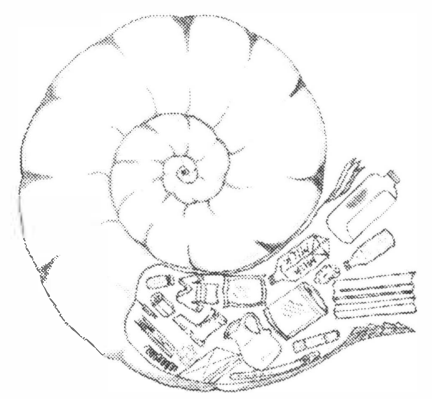

Figure 6. No all that we throw away is waste: we can recycle instead.

\section{Costs}

The cost of this project must cover, at a minimum, factors listed in table 1 .

Table 1. Minimum costs to consider for this project.

\begin{tabular}{|c|c|c|}
\hline Personnel & Publicity & Tools and Equipment \\
\hline Advisors, & Printing, & Transportation, \\
Supervisors, & Pamphlets, & Laptop, \\
Promoters, & Videos, & Projector, \\
Volunteers & TV, & Guides and/or \\
& Radio, & Manuals \\
& Workshops, & \\
& Theatre, & \\
& Etc. & \\
\hline
\end{tabular}

Costs will vary according to zone. 


\section{ADVANTAGES AND BENEFITS}

1. As a result of this project, reuse and recycling will increase, while the volume of solid wastes generated will decrease.

2. The volume of solid waste collected for recycling will increase by at least $80 \%$.

3. The volume of recyclable, reusable, and organic solid wastes that end up in the landfill will decrease by $90 \%$. Costs from the transfer of solid waste to landfills will decrease.

4. Recycling will translate to the preservation of both renewable and nonrenewable resources, because the demand on new raw materials will decrease.

5. Recycling generates income and employment for industries and municipalities through the sale of recycled materials. Solid wastes are decreased at the same time.

6. Within a period of two years, the population will undergo a radical attitude change regarding the management of urban solid waste.

\section{CONCLUSIONS AND RECOMMENDATIONS}

The difference between waste and solid waste is the way in which they are discarded - we must learn to recycle that which we no longer need.

Remember that waste is a problem that can diminish notably if solid wastes are adequately separated.

Education is essential before beginning a program. Everyone should participate.

Each person who has been educated about solid waste and recycling should be encouraged to pass on the message to members of his/her community, family, friends, or acquaintances, so that educational programs both continue and improve, and the recommended waste management practices are carried out..

A program of permanent information diffusion must be established to stress the importance of separating and recycling solid wastes at all social and political levels.

Make "black gold" or compost with leaves, plants, and organic wastes.

Disseminate educational videos of not more than 10 minutes.

Create clubs.

Promote recycling of old computers by restoring and renovating components for use in classes, computer labs, and students' homes. Use them for learning about machines and technology.

\section{REFERENCES}

[1] Agencia de Cooperación Internacional de Japón (JICA) -1999. "Estudio sobre el manejo de residuos sólidos para la ciudad de México de los Estados Unidos Mexicanos". Vol. 1, Mayo Diagnóstico de la situación del manejo de residuos sólidos Municipales en América Latina y el Caribe. Segunda edición. Washington, D. C. (In Spanish).

[2] INEGI. Con base en SEDESOL. DGOT. Subdirección de Asistencia Técnica a Organismos Operadores Urbanos Regionales. Fecha de actualización: Viernes, 21 de abril de 2006. (In Spanish).

[3] Soler Pérez de Salazar M. J., Ramos Guevara, E, Paredes Alvarado, R. P., 2006 "Inventario de Residuos Sólidos del Distrito Federal" GDF. 70 pp. (In Spanish) 
[4] Tchobanoglous George, Theinsen Hilary, Vigil Samuel -1993. "Integrated Solid Waste Management". Engineering Principles and Management Issues. McGraw-Hill. International Editions.

[5] Ley general para la prevención y gestión integral de los residuos.

Nueva Ley publicada en el Diario Oficial de la Federación el 8 de Octubre de 2003. (In Spanish).

[6] Ley de Residuos Sólidos del Distrito Federal Publicada en la Gaceta Oficial del Distrito Federal el 22 de abril de 2003 (In Spanish).

[7] Deffis Caso A. (1989) La casa ecológica autoeficiente (para clima templado y frío) Ed. Concepto, J. A., pág. 167-192 (In Spanish). 